\title{
Dokumenty potwierdzenia praw miejskich Firleja
}

abstrakt: Miasto Firlej w województwie lubelskim - w XVI-XVIII w. noszące nazwę Firlejów - według dawnej literatury historycznej lokowane było w 1557 r. dzięki staraniom Mikołaja Firleja. Przywilej lokacyjny tego miasta nie jest znany, jedynie wzmianki z dawnego archiwum skarbowego oraz ksiąg miejskich pobliskiego Lubartowa z II połowy XVI w. poświadczają istnienie tego miasta. Dokumenty potwierdzające lokację miasta i nadanie mu prawa miejskiego pochodzą z XVII i XVIII w. Prawo miejskie Firleja w 1688 r. potwierdził ówczesny właściciel miasta Józef Karol Lubomirski. Kolejny dziedzic miasta Paweł Karol Sanguszko wydał dwa dokumenty potwierdzające prawa miejskie Firleja - w 1712 i 1739 r. W świetle tych dokumentów oraz ksiąg miejskich Firlejowa miasto funkcjonowało według norm prawa miejskiego magdeburskiego od około $1690 \mathrm{r}$.

sŁowa KLUCzowe: Firlej, Firlejów, lokacja, prawo miejskie, prawo magdeburskie, dokument lokacyjny.

W Zbiorze dokumentów pergaminowych Archiwum Głównego Akt Dawnych w Warszawie znajdują się trzy dokumenty dziedziców miasta Firleja, dawniej zwanego Firlejowem, z lat 1688, 1712 i $1739^{1}$. Dokumenty te potwierdzają prawo miejskie Firleja oraz regulują szereg szczegółowych uprawnień, zwanych prawami miasta, w zakresie sądownictwa i organizacji życia gospodarczego. Wśród postanowień dokumentów właścicieli Firleja wiele dotyczyło swobód i wolności mieszczan firlejowskich, a także ich powinności względem władzy zwierzch-

1 Archiwum Główne Akt Dawnych (dalej AGAD), Zbiór dokumentów pergaminowych, sygn. 5784, 5752, 6390 . 
niej. Publikowane poniżej dokumenty pozostawały na uboczu dotychczasowych badań, w odniesieniu do dziejów Firleja prowadzonych dla okresu wcześniejszego, czyli lokacji miasta w XVI w. ${ }^{2}$, oraz organizacji kancelarii miejskiej Firleja (po 1688 r.) $)^{3}$. Informacje o postanowieniach dokumentów dziedziców Firleja przytoczone zostały w ostatnio wydanej publikacji poświęconej przeszłości tego miasta ${ }^{4}$.

Lokacja miasta Firlejowa łączona jest z osobą Mikołaja Firleja (1531-1588), kasztelana wiślickiego, syna wojewody ruskiego Piotra Firleja z Dąbrowicy, założyciela m.in. Lewartowa, który stał się siedzibą klucza dóbr. Literatura przedmiotu z XIX w. jako datę lokacji miasta upowszechniła rok $1557 \mathrm{r}^{5}$ Weryfikacja ustaleń o początkach Firlejowa w nowszych badaniach nie przyniosła dowodów źródłowych prawnej lokacji miasta w postaci królewskiego przywileju lokacyjnego czy dokumentu lokacyjnego właściciela. Niemniej jednak źródła z XVI w. potwierdzają opinię o założeniu Firlejowa przez Mikołaja Firleja, ale także o możliwym rozpoczęciu procesu lokacji miasta pod pierwotną nazwą Serock jeszcze przez Piotra Firleja. Przemawiają za tym zapiska o mieście Serocku z 1553 r. ${ }^{6}$, wzmianki ze źródeł dawnego archiwum skarbowego o opłacaniu przez miasto podatków ${ }^{7}$ oraz wzmianki z ksiąg miejskich sąsiedniego Lewartowa z II połowy XVI w. ${ }^{8}$ Odnajdywane kolejne zapiski ze źródeł pochodzących z dawnego archiwum skarbowego oraz ksiąg miejskich Lewartowa przynoszą jedynie dalsze przykłady znanych już świadectw miejskiego statusu Firlejowa w latach 6o.-80. XVI w. ${ }^{9}$

Dokumenty potwierdzające miejski status Firlejowa pochodzą dopiero z II połowy XVII i XVIII w. Najpierw w 1688 r. prawo miejskie potwierdził dziedzic Firlejowa i całego klucza lewartowskiego Józef Karol Lubomirski, natomiast w 1712 i 1739 r. podobne dokumenty wystawił kolejny właściciel Paweł Karol Sanguszko. Posesorzy potwierdzili prawo miejskie, którym miasto rządziło się od swych początków, daty jednak nie przywołano. W dokumentach na powrót organizujących życie miejskie Firlejowa odwołano się jedynie do przeświadczenia

${ }^{2}$ R. Szczygieł, Lokacje miast w Polsce XVI wieku, Lublin 1989, s. 250-251.

${ }^{3} \mathrm{~J}$. Łosowski, Kancelarie miast szlacheckich województwa lubelskiego od XV do XVIII wieku, Lublin 1997, s. 85.

${ }^{4}$ H. Seroka, Firlejów - zarys dziejów dawnego miasteczka, Lublin 2017, s. 11-23.

${ }^{5}$ M. Baliński, T. Lipiński, Starożytna Polska pod względem historycznym, geograficznym i statystycznym. T. 3, Warszawa 1886, s. 283.

${ }^{6}$ R. Szczygieł, Lokacje miast, s. 255.

7 Tamże, s. 250.

${ }^{8}$ R. Szczygieł, Poczatki miasta Lewartowa na tle rozwoju miast prywatnych w Polsce XVI wieku, „Lubartów i Ziemia Lubartowska”, 1983, s. 47.

${ }^{9}$ H. Seroka, Firlejów, s. 8-9. 
o przywilejach danych miastu przez poprzednich dziedziców, których zapis uległ zniszczeniu podczas pożaru miasta. Dokument Józefa Karola Lubomirskiego potwierdzał prawo miejskie bez precyzowania szczegółów, poprzestając na zrównaniu Firlejowa w prawach miejskich z Lewartowem. Określenie rodzaju prawa miejskiego jako prawa magdeburskiego, które w 1543 r. otrzymał Lewartów ${ }^{10}$, uszczegółowione zostało w dokumencie wystawionym przez Pawła Sanguszkę w 1712 r. Potwierdzenie prawa miejskiego w 1688 r. przez wskazanie modelu organizacji miasta Lewartowa oraz wskazanie prawa magdeburskiego w $1712 \mathrm{r}$. w połączeniu ze sformułowaniem o utracie pierwotnych dokumentów miasta oraz regulacjami ekonomicznymi na nowo określiły ramy prawne funkcjonowania miasteczka.

Główne postanowienie dokumentów dla Firlejowa, czyli potwierdzenie jego prawa miejskiego, podobne są do królewskich przywilejów potwierdzenia i odnowienia prawa miejskiego. Włączenie do dokumentów szeregu postanowień dotyczących organizacji życia miasta: prawa do sądu miejskiego, zakładania cechów, odbywania jarmarków, zwolnienia od podatków miejskich (wolności), swobodnego osadzania się w mieście oraz warzenia i szynkowania piwa (swobód) wraz z zapowiedzią określenia czynszów i powinności względem dworu, zbieżne jest $\mathrm{z}$ treściami dokumentów lokacyjnych właścicieli miast. Zwraca również uwagę powtarzanie postanowień z 1688 r. w dokumentach Pawła Karola Sanguszki: pierwszym wydanym za życia małżonki Marii Anny z Lubomirskich, dziedziczki miasta, w 1712 r. oraz drugim z 1739 r., wydanym już po jej śmierci. Aktualizacja praw miejskich po zmianie właściciela miasta ma analogię w praktyce dokumentów powtarzających (transumptów), wydawanych przez kolejnych władców miastom królewskim. W dokumentach Pawła Karola Sanguszki dokumenty nadawane miastu od 1688 r. określano jako „przywileje”. Dodajmy przy tym, że miasto tylko raz otrzymało przywilej wydany przez króla, a był nim dokument wydany w Grodnie 12 XI 1744 r. przez Augusta III Sasa informujący o nadaniu prawa do odbywania w mieście jarmarków ${ }^{11}$. W tymże roku Sanguszko uzyskał jeszcze drugi przywilej królewski dla miasta należącego do jego dóbr: odnowienie prawa miejskiego Lewartowa w dokumencie wydanym w Grodnie 22 XI 1744 r., w którym znalazło się potwierdzenie zmiany nazwy miasta na Lubartów i nadania miastu nowego herbu ${ }^{12}$. Oprócz dokumentów potwierdzających prawa miejskie z 1688, 1712 i 1739 r. oraz

\footnotetext{
10 R. Szczygieł, Lokacje miast, s. 252.

11 AGAD, Metryka Koronna, Sigillata, ks. 26, k. 255v.

12 H. Seroka, Herby miast małopolskich do końca XVIII wieku, Warszawa 2002, s. 280.
} 
przywileju nadania prawa do odbywania jarmarków z 1744 r. miasto posiadało jeszcze dwa inne dokumenty papierowe, wydane przez dziedziców, dotyczące zagadnień ekonomicznych. W 1700 r. dziedziczka Firlejowa Teofila Ludwika z Zasławskich Lubomirska, żona Józefa Karola Lubomirskiego, nadała prawo sycenia miodów, kurzenia gorzałki i produkcji wina oraz zwalniała mieszczan od czynszów i powinności na okres siedmiu lat. W 1796 r. syn Pawła Karola Sanguszki, Janusz Modest Sanguszko, zrównywał w powinnościach względem dworu ludność żydowską z chrześcijańską, nadawał prawo wrębu do swoich lasów przy budowie nowych domów oraz zapowiedział nadanie mieszczanom nowych gruntów ${ }^{13}$.

Podstawą wydania tekstu dokumentów są ich oryginały. Uwzględnione zostały, skądinąd nieliczne, odmianki tekstowe kopii, jeśli wykraczały poza ortografię i interpunkcję oraz skrócenia wyrazów oryginału. Pisownię zmodernizowano zgodnie z zaleceniami „Instrukcji wydawniczej dla źródeł historycznych od XVI do połowy XIX wieku”. Bez ingerencji natomiast pozostawiony został zwrot „miasto Firlejowskie", wyrazy i zwroty zlatynizowane i łacińskie wyróżniono. Układ redakcyjny wydawanego dokumentu przyjęto za wydawnictwami dyplomatycznymi, zachowując też zaznaczenie rozwiązania pism skróconych. Opuszcza się objaśnienie występujących w dokumentach nazw geograficznych miast województwa lubelskiego, w tym Firleja do końca XVIII w. nazywanego Firlejowem oraz Lubartowa do około 1739-1744 r. nazywanego Lewartowem.

\section{Summary}

\section{Documents of Confirmation of Town Rights of Firlej}

Firlej, a town in Lublin province, was called between the sixteenth and eighteenth centuries after the Firlej family. According to historical literature it was founded in 1557 due to the endeavors of Mikołaj Firlej. The foundation charter is not known; only some references from the Treasury Archive and town books of the nearby Lubartów of the second half of the $16^{\text {th }}$ century confirm the existence of this town. The documents which attest to the foundation of the town and granting a foundation charter come from the seventeenth and eighteenth centuries. The then owner of the town, Józef Karol Lubomirski, confirmed the town rights of Firlej in 1688. The subsequent heir of the town, Paweł Karol Sanguszko,

\footnotetext{
${ }^{13}$ H. Seroka, Firlejów, s. 18-19, 23-24.
} 
issued two documents which certified the town rights of Firlej in 1712 and 1739. According to these documents and the town books of Firlej, the town operated under the Magdeburg town law since circa 1690.

KEYwORDs: Firlej, Firlejów, foundation of town, Magdeburg law, foundation charter.

\section{Teksty źródłowe}

1.

Lublin, 24 lipca 1688 r. Józef Karol Lubomirski koniuszy koronny, potwierdza prawo miejskie Firlejowa zrównując je $z$ Lewartowem, $z$ prawem do sadu miejskiego, zakładania cechów, warzenia i szynkowania piwa, odbywania czterech jarmarków oraz określa ogólnie czynsze i powinności mieszczan.

Oryg.: Archiwum Główne Akt Dawnych (dalej AGAD), Zbiór dokumentów pergaminowych, sygn. 5784 . Dokument pergaminowy, $35,5 \times 25,5 \mathrm{~cm}+3,5 \mathrm{~cm}$, karta pergaminowa złożona podwójnie. Zachowany w dobrym stanie, pismo staranne, nieco wyblakłe, w miejscach złożenia dokumentu oraz z prawej strony niektóre wyrazy słabo czytelne. Pasek jedwabny czerwony po pieczęci. Druga pieczęć odciśnięta na pergaminie, poniżej tekstu, na podkładzie z masy pieczętnej nałożonej między kartami, ok. $52 \mathrm{~mm} \times 47 \mathrm{~mm}$, nieczytelna.

Kopie: 1. Archiwum Państwowe w Lublinie (dalej APL), Akta miasta Firleja, sygn. 1, s. 9 (kopia z 1690 r.); 2. AGAD, Komisja Rządowa Spraw Wewnętrznych, sygn. 3195a, s. 269 (kopia z 1821 r.).

Streszczenie z 1690 r.: APL, Akta Miasta Firleja, sygn. 1, s. 7.

Józef Karol hrabia na Wiśniczu, Jarosławiu i Tarnowie Lubomirski, koniuszy koronny, sandomierski, zatorski, niepołomskia, solecki, lubaczowski, lubomlski, rycki et c(etera) starosta ${ }^{1}$. Wiadomo czynię, komu o tym teraz i na po tym wie-

a Opuszczone, kop. 1.

${ }^{1}$ Józef Karol Lubomirski (ok. 1660-1712), koniuszy koronny (1683? 1684-1692). 
dzieć będzie nalało. Iż chcąc w jako najlepszym mieća porządku i do pierwszej przyprowadzić pory miasteczko moje Firlejów, któremu prawa wszystkie na których zasiadło od antecesorów moich nadane pogorzały, przeto przychylając się do supliki mieszczan ${ }^{\mathrm{b}}$ i obywatelów tamecznych, do wszystkich praw, swobód i wolności, jakie ma miasto moje Lewartów, onychże przypuszczam, i aby takoweż między sobą sądy, obrzędy i jurysdykcje mieli, wyraźnie mieć chcę i wiecznemi czasy przy tym conserwować onych deklaruję. Rzemieślnikom także wszelkiego rzemiosła cechy i ustawy swoje, tak jako i w innych miastach, mieć o odprawować pozwalam. Więc i szynkowanie piwa wolne mieć będą, byle należytość arendarską według zwyczaju i postanowienia, to jest po złotych sześciu od czterech korcy miary lewartowskiej oddawali. W tymże mieście podług dawnych praw jarmarki ${ }^{1}$ cztery do roku odprawować się mają bez wszelkiej przeszkody. Powinności jednak wszelakie, czynsze i roboty pewne w inwentarzu opisane, do zamku lewartowskiego odbywać będą powinni. Zachęcając przy tym do osiadłości i budowania się w tym miasteczku, przeto każdemu ktokolwiek by się tam fundować chciał i osiąść, do lat sześciu od wszelkich podatków i powinności dworskich nadaję wolności. Na co dla większejc wagi własną podpisuję się ręką i pieczęć przycisnąć rozkazałem. Dat (um) w Lublinie, dnia dwudziestego czwartego miesiąca lipca roku pańskiego tysiącznego sześćsetnego osiemdziesiątego ósmego.

[podpis] J(ózef) Lubomirski koniuszy koronny m(anu) p(ropria).

a Opuszczone, kop. 2.

b Mieszczanów, kop. 1.

c Lepszej, kop. 1.

${ }^{1}$ Przywilej na jarmarki Firlejów otrzymał od Augusta III Sasa w 1744 r. 
2.

Lewartów, 20 maja 1712 r. Paweł Karol Sanguszko podskarbi nadworny litewski, potwierdza prawo miejskie miastu Firlejów na wzór miasta Lewartowa, z prawem do sądu miejskiego, cechów rzemieślniczych, warzenia i szynkowania piwa, czterech jarmarków, a także określa ogólnie czynsze i powinności mieszczan.

Oryg.: Archiwum Główne Akt Dawnych (dalej AGAD), Zbiór dokumentów pergaminowych, sygn. 5752 . Dokument pergaminowy, $30 \times 37 \mathrm{~cm}+2-2,5 \mathrm{~cm}$ zakładka. Zachowany w dobrym stanie, pismo staranne, czytelne. Puszka po pieczęci mosiężna na pasku jedwabnym czerwonym, bez zamknięcia, o średn. $6,5 \mathrm{~cm}, \mathrm{z}$ drobnymi resztkami czerwonej masy pieczętnej. Pod tekstem dokumentu podpis wystawcy. Na odwrociu dawne sygnatury. Kopia: AGAD, Komisja Rządowa Spraw Wewnętrznych, sygn. 3195a, s. 273 (kopia z 1821 r.).

Paweł Karol książę na Białym Kowlu i Solanach Lubartowicz Sanguszko ${ }^{1}$ podskarbi nadworny Wielkiego Księstwa Litewskiego. Oznajmuję wszem wobec i każdemu z osobna komu o tym wiedzieć należy, iż mając osobliwy respekt na miasto moje Firlejów, a chcąc one w jako najlepszym porządku zachować, tudzież mając wzgląd na supliki poddane, ponieważ interweniente incendio, dawne temu miastu nadane prawa pogorzały, umyśliłem pomienione miasto Firlejów do wszystkich

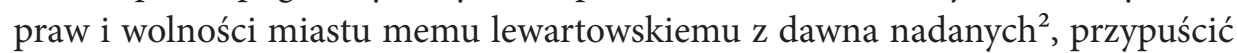
i przyłączyć, jakoż niniejszym przywilejem moim przypuszczam i przyłączam. I aby takoweż sądy, obrzędy i jurusdykcje między sobą mieli, mieć chcę i wiecznemi czasy przy tym miasto moje Firlejów zachować deklaruję. Rzemieślnikom także wszelkiego rzemiosła cechy i ustawy swoje trybem innych miast mieć i odprawować pozwalam. Szynkowanie piwa wolne mieć mają, oddawszy należytość arendarską, to jest złotych sześć od czterech korcy miary lewartowskiej. W tymże mieście jarmarki cztery ${ }^{3}$ do roku odprawować się mają bez wszelkiej przeszkody. Powinności zaś, wszelkie czynsze i roboty pewne w inwentarzu wyrażone, wypłacać i odprawować powinni będą. Zachęcając przy tym do osiadłości i budowania się w tym miasteczku Firlejowskim, każdemu kto by się tam de novo garnął, osiadał i budował, wolność od wszelkich podatków i powinności do dworu mego należą-

\footnotetext{
${ }^{1}$ Paweł Karol Sanguszko (1680-1750), podskarbi nadworny litewski od 1709 r.

2 Przywilej lokacyjny Lewartów otrzymał od Zygmunta I Starego w 1543 r.

${ }^{3}$ Por. dok. nr 1, przypis 2.
} 
cych na lat sześć daję i pozwalam. I na to dla lepszej wagi do tego przywileju, ręką się moją podpisawszy, pieczęć przycisnąć rozkazałem. Działo się w Lewartowie, dnia dwudziestego maja roku pańskiego tysiąc siedemset dwunastego.

[podpis] Paweł książę Lubartowicz Sanguszko podsk(arbi) n(adworny) W(ielkiego) $\mathrm{K}$ (sięstwa) L(itewskiego) $m$ (anu) p(riorpria).

3.

Lubartów, 7 stycznia 1739 r. Pawet Karol Sanguszko marszałek wielki litewski, starosta czerkaski, potwierdza miastu swojemu dziedzicznemu Firlejów dwa przywileje, pierwszy Józefa Karola Lubomirskiego $z 1688$ r. oraz drugi wydany przez siebie $w 1712$ r., zawierajace potwierdzenie prawa miejskiego (magdeburskiego), z prawem do sadu miejskiego, odbywania jarmarków, zakładania cechów, ważenia i szynkowania piwa, oraz określające czynsze i powinności mieszczan.

Oryg.: Archiwum Główne Akt Dawnych (dalej AGAD), Zbiór dokumentów pergaminowych, sygn. 639o. Dokument pergaminowy, $65 \times 27 \mathrm{~cm}+6,5 \mathrm{~cm}$ zakładka. Zachowany $\mathrm{w}$ dobrym stanie, pismo staranne, czytelne, nieco wyblakłe, intytulacja wyróżniona większym modułem pisma. Pieczęć na pasku jedwabnym czerwonym, odciśnięta w masie pieczętnej czerwonej, w puszce metalowej o średn. $6,5 \mathrm{~cm}$, bez zamknięcia. Na pieczęci herb rodowy Sanguszków Pogoń, po bokach tarczy herbowej żołnierze-trzymacze, nad tarczą z położonymi pod nią laskami marszałkowskimi skrzyżowanymi w skos mitra książęca, poniżej tarczy - order. W otoku pieczęci legenda, słabo odciśnięta. Pod zakładką podpisy wystawcy i pisarza. Na odwrociu dawne sygnatury.

Kopia: AGAD, Komisja Rządowa Spraw Wewnętrznych, sygn. 3195a, s. 275 (kopia z 1821 r.).

Paweł Karol Lubartowicz na Białym Kowlu, Smolanach i Rakowie książę Sanguszko, marszałek wielki Wielkiego Księstwa Litewskiego, czerkaski starosta, na całym księstwie zasławskim i dobrach Lubartowie, Firlejowie, Kijanach, Jakubowicach i Łące, pan i dziedzic ${ }^{1}$. Wiadomo czynimy, komu o tym wiedzieć należy albo by na potem wiedzieć należało. Iż mieszczanie nasi miasteczka Firlejowa do

${ }^{1}$ Paweł Karol Sanguszko (1680-1750), stolnik litewski od 1708 r., podskarbi nadworny litewski od 1709 r., marszałek nadworny litewski od 1713 r., marszałek wielki litewski od 1734 r. 
klucza lubartowskiego z dawna należącego, produkowawszy przed nami przywileje dwa praw swoich, pierwszy od świętej pamięci jaśnie wielmożnego jego mości pana Józefa Karola hrabiego na Wiśniczu i Jarosławiu Lubomirskiego ${ }^{1}$ koniuszego koronnego na porównanie tychże mieszczan firlejowskich w prawach, swobodach i wolnościach, sądach, obrzędach, cechach rzemieślniczych z mieszczanami tutejszymi przedtem lewartowskimi a teraz lubartowskimi ${ }^{2}$ nazwanymi, z pozwoleniem wolnego szynku piwa, jarmarków i innych rzeczy, de data w Lublinie dnia dwudziestego czwartego miesiąca lipca a roku pańskiego tysiącznego sześćsetnego osiemdziesiątego ósmego dany ${ }^{3}$ a drugi na toż samo od nas samych za życia ś(więtej) p(amięci) j(aśnie) o(świeconej) k(siężnej) jejm(ość) Marii Anny z Lubomirskich $^{4}$ najukochańszej małżonki naszej a tego miasteczka między innymi dobrami dziedziczki, w Lewartowie dnia dwudziestego miesiąca maja a roku pańskiego tysiącznego siedemsetnego dwunastego nadany ${ }^{5}$. Suplikowali, abyśmy im te prawa i przywileje po zgorzeniu dawniejszych otrzymane, jako teraźniejszy ich pan i nowy dziedzic łaskawie potwierdzić przy nich i wolnościach im według ich pozwolonych i dotąd w używaniu będących, na potomne czasy zachować raczyli. Zaczym my, jako tego najbardziej pragniemy, aby pod panowaniem naszym daj Boże szczęśliwym, ludzie poddani nasi przy swoich swobodach [i] prawach bezpiecznymi zostawalia a miasta, i to miasto Firlejów, w większą ludzi przez to osadę pomnażać się mogły, tak do supliki tychże obywateli i mieszczan firlejowskich skłoniwszy się, namienione prawa i przywileje ich, które za wpisane $\mathrm{w}$ ten przywilej poczytane być mają, władzą i powagą naszą pańską aprobowaliśmy, jako niniejszym przywilejem we wszystkim te przywileje i prawa aprobujemy, ratyfikujemy [i] konfirmujemy. A według tych praw przy wszelkich sądów miejskich i rządów prawem magdeburskim, tudzież cechów rzemieślniczych i handlów wszelkich (na co komu stać może) na wzór miasta Lubartowa [w] prerogatywach, swobodach, wolnościach i jarmarkach czterech do roku pozwolonych, także przy wolnym warzeniu i szynkowaniu piwa zapłaciwszy to do arendy skarbu naszego, co w przywilejach tych jest wyrażono i naznaczono, to jest po złotych sześciu od czterech korcy lubartowskich,

\footnotetext{
a Zostawać, or.

${ }^{1}$ Zob. dok. nr 1, przypis 1.

${ }^{2}$ Zmianę nazwy miasta Lewartów na Lubartów potwierdził król August III Sas w przywileju $\mathrm{Z} 1744 \mathrm{r}$.

${ }^{3}$ Zob. dok. nr 1.

${ }^{4}$ Maria Anna z Lubomirskich Sanguszkowa (zm. 1729 r.), druga żona Pawła Karola Sanguszki (od $1710 \mathrm{r}$.).

${ }^{5}$ Zob. dok. $\mathrm{nr} 2$.
} 
tychże mieszczan naszych firlejowskich na potomne i wieczne czasy zachować deklarujemy a po nas potomków naszych obowiązujemy. Powinności zaś swoje zwykłe, jako czynsze, kapłony, jaja, ospy owsowe i niektóre robocizny, według inwentarza anni 1728 skarbowi naszemu płacić, oddawać i odbywać corocznie powinni. A nad opisanie tego samego anni 1728 inwentarza do niczego więcej od rządców dóbr naszych, żadnym pretekstem i sposobem, pociągani i aggrawowani ciż mieszczanie firlejowscy być nie mają. Którym przyzwoitą naszą w wszelkich okazjach, aby gwałtów i krzywd od nikogo nie cierpieli, dawać obiecujemy protekcję i do dawania onej namiestników naszych obowiązujemy. A jeżeliby kto obcy, czy chrześcijanin lub też i żyd, w tym miasteczku chciał osiąść i de novo się budować, tedy takowemu wolności od powinności wszelkich skarbowi naszemu należących na lat sześć dać deklarujemy i ex nunc pozwalamy. W czym wszystkim dla lepszej wiary, wagi i pewności ręką własną podpisawszy się, pieczęcią zwykłą ten przywilej stwierdzić rozkazaliśmy. Dat(um) w pałacu lubartowskim, dnia siódmego miesiąca stycznia a roku pańskiego tysiącznego siedemsetnego trzydziestego dziewiątego.

[podpisy] Paweł książę Sanguszko Lubartowicz, marszałek w(ielki) W(ielkiego) K(sięstwa) L(itewskiego), starosta czerkaski, dziedzic Lubartowa i Firlejowa. Jacek Kazimierz Ratajewicz, sigillatum die et anno ut supra, j(aśnie) o(świeconego) księcia j(ego) m(oś)ci sekretarz m(anu) p(ropria). 


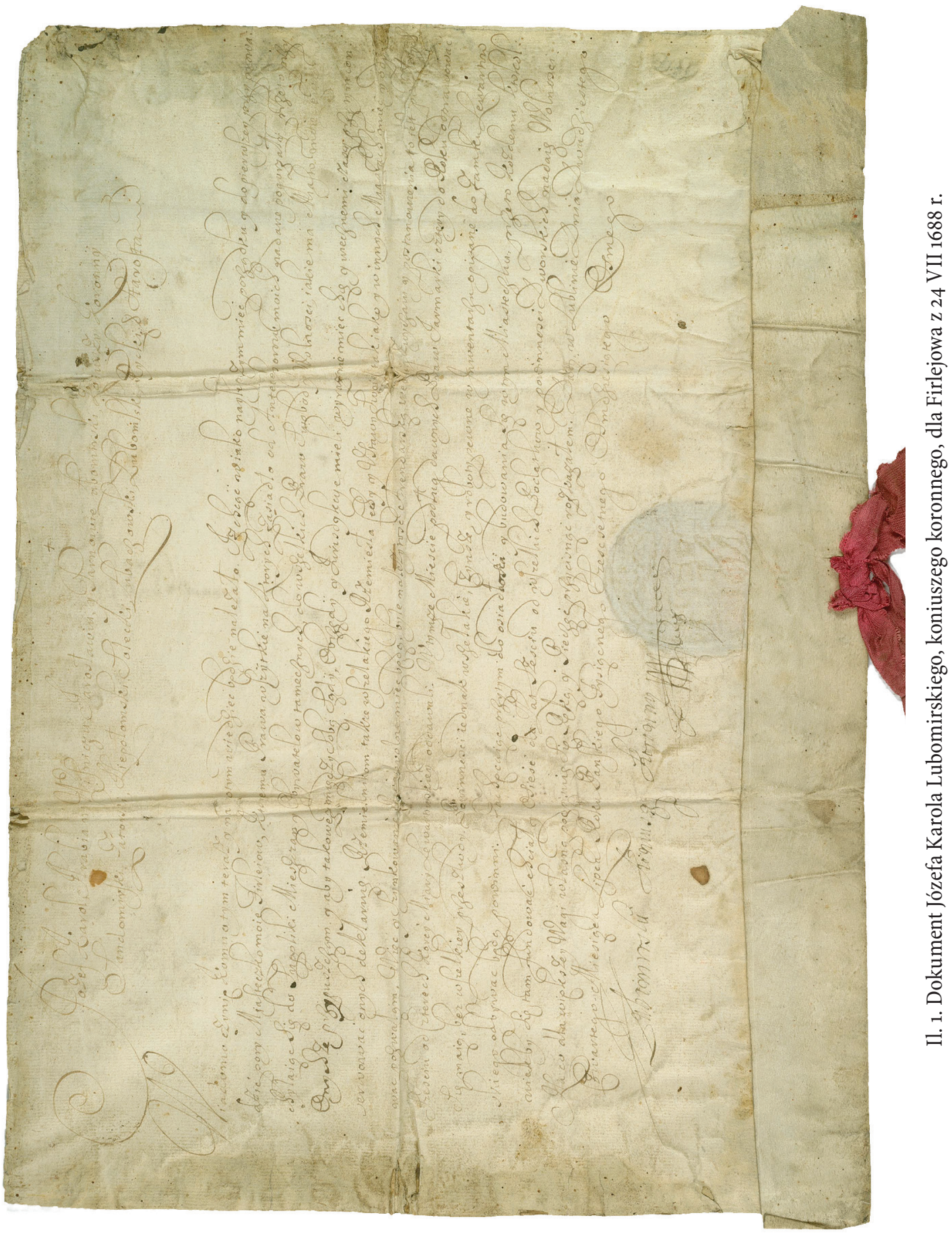




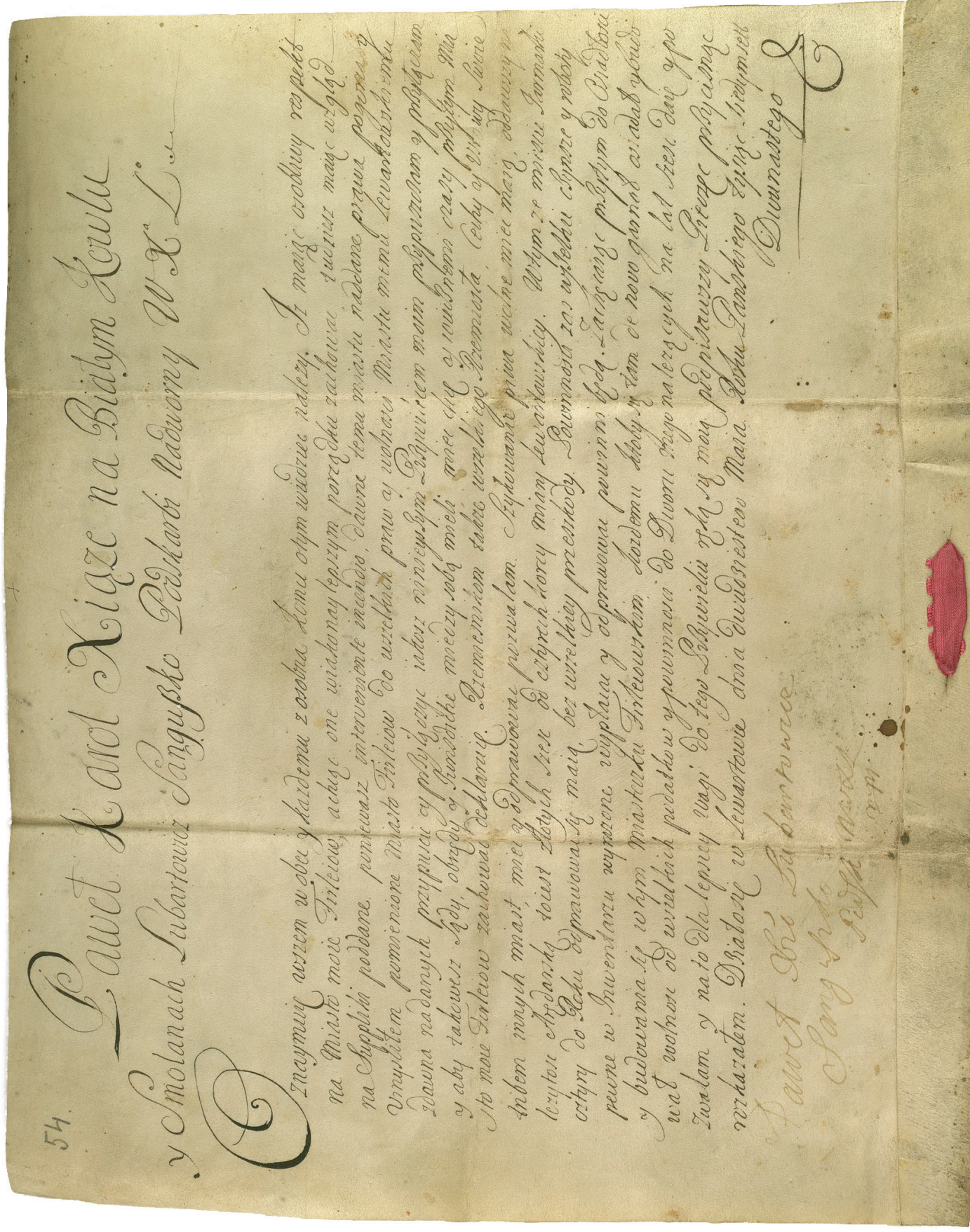




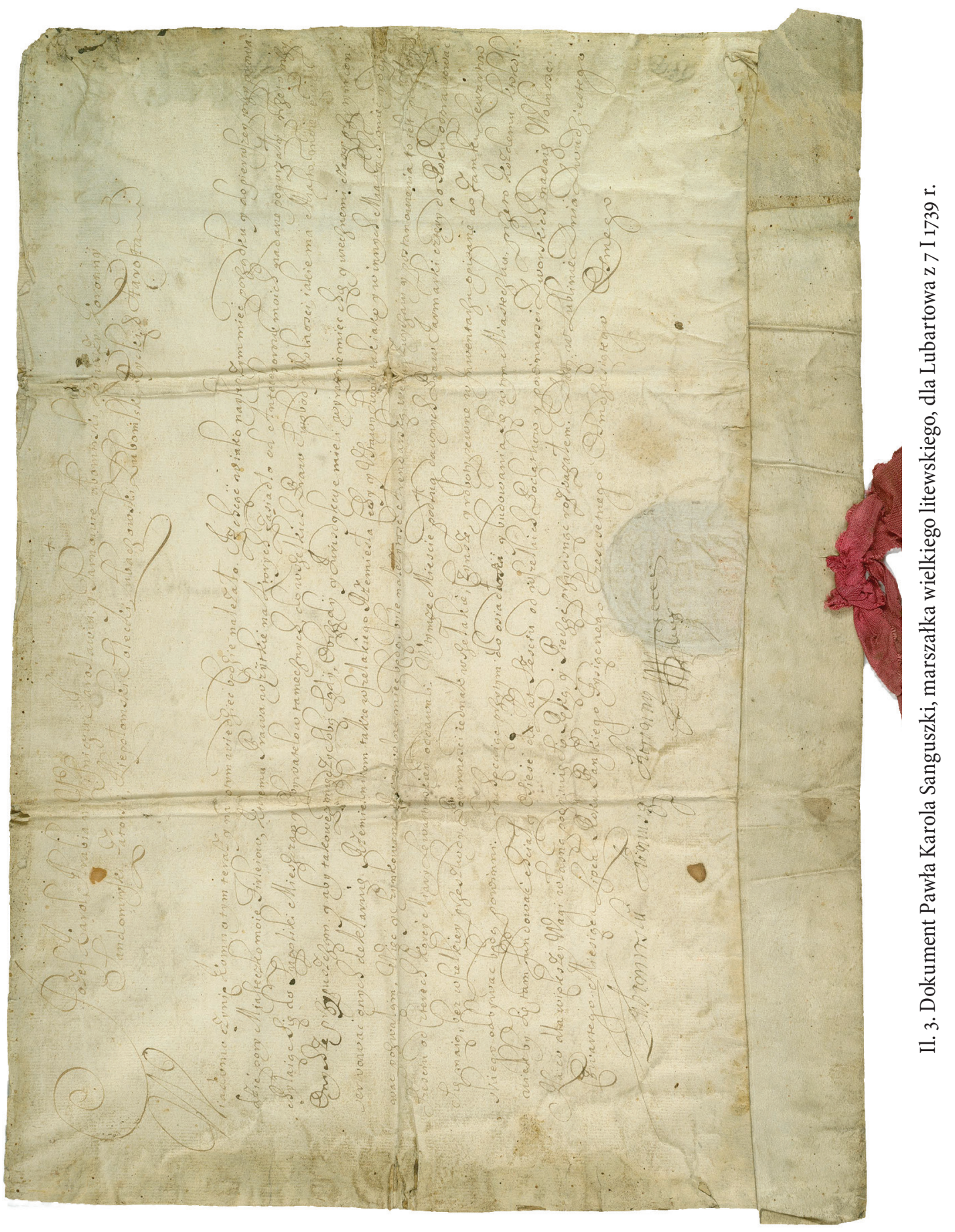

